\title{
THE INCIDENCE OF THE VARIOUS TYPES OF PNEUMOCOCCI IN INFECTIONS OTHER THAN PNEUMONIA
}

\author{
BY \\ R. W. FAIRBROTHER, M.D.(VICt.), M.R.C.P.(LoND.). \\ (From the Department of Bacteriology and Preventive Medicine, University \\ of Manchester.)
}

The pneumococcus is not infrequently responsible for infections other than pneumonia and in these cases the typing of the causative organism is a matter of some importance. It is now accepted that the typing of strains of the pneumococcus isolated from cases of pneumonia constitutes an important part of the bacteriological examination of material obtained from such cases. This is particularly emphasized by the conclusive demonstration of the value of specific serum therapy in cases of type I pneumonia. While the same practical value has not been attached to the typing of pneumococci obtained from other infections, the results given below provide some interesting data.

It has been observed both in America and in this country that empyema is more frequently caused by the type I pneumococcus than by any other type. Cecil and Plummer ${ }^{2}$ stated that empyema was twice as common in type I than in type II pneumonia, while endocarditis was more frequent after type II infection. Whittle ${ }^{5}$ found 24 out of 31 cases of empyema to be due to the type I pneumococcus and Smeall ${ }^{4} 14$ out of 21 cases. Glynn and Digby $^{3}$ also isolated the type I pneumococcus with the greatest frequency from cases of empyema. Blacklock and Guthrie ${ }^{1}$ found that while in children group IV strains predominated in the empyemata following bronchopneumonia, the incidence of fixed types rose with the age of the child. From these cases the type I pneumococcus was usually obtained.

The following results were obtained from the examination of material obtained from cases, mainly children of school age, in the Manchester district between 1932-1934. Cultures were made on blood agar, from which single colonies were placed into tubes of Hartley broth. These cultures were employed for a macroscopic agglutination test after a preliminary test for 
bile solubility. The frequency with which the various types were encountered is shown in the table:-

\begin{tabular}{|c|c|c|c|c|c|c|}
\hline & & & YYPE & & Group & Total \\
\hline & & I & II & III & IV & \\
\hline ЕMPYEMA & $\ldots$ & 51 & 4 & - & 4 & 59 \\
\hline MENINGITIS & $\ldots$ & 5 & 4 & 1 & 2 & 12 \\
\hline OTHER CONDITIONS & $\cdots$ & 1 & 1 & 1 & 1 & 4 \\
\hline & & - & - & - & - & - \\
\hline & & 57 & 9 & 2 & 7 & 75 \\
\hline & & 一 & - & 一 & - & - \\
\hline
\end{tabular}

One point is outstanding and that is the high incidence, 87 per cent., of the type I pneumococcus in cases of empyema. In other infections examined there was no such tendency to predilection of type.

This raises an important question. Pneumococcal empyema is invariably a sequel to pneumonia, and the remarkable frequency with which the type I organism is isolated, is considered to be an indication of the marked invasiveness of this type of pneumococcus. It is now generally accepted that this is also the type of pneumonia which responds well to serum therapy. These facts suggest that as early serum therapy of type I pneumonia becomes more widely applied the incidence of empyema should decrease. The above figures have been obtained from patients who had not received serum and probably serve to emphasize the necessity for the early administration of serum in cases of type I pneumonia.

\section{REFERENGES.}

1. Blacklock, J. W. S., \& Guthrie, K. J., J. Path. Bact., Edin., 1933, XXXVI, 349 .

2. Cecil, R. L., \& Plummer, N., J. Am. Med. Ass., Chicago, 1932, XCVIII, 779.

3. Glynn, E. E., \& Digby, L., Med. Res. Council, Spec. Rep. Series, No. 79, 1923.

4. Smeall, J. T., Brit. Med. J., Lond., 1931, i, 661 .

5. Whittle, C. H., ibid, 1929, ii, 898. 